\title{
Patient's Awareness of Dental Implant as an Option for Missing Teeth in Chitwan, Nepal
}

\author{
Smriti Narayan Thakur ${ }^{4}$ Dinesh Rokaya ${ }^{5}$ \\ ${ }^{1}$ Department of Dentistry, Tribhuvan University Institute of \\ Medicine, Kathmandu, Nepal \\ ${ }^{2}$ Department of Orthodontics, Chitwan Medical College, \\ Chitwan, Nepal \\ ${ }^{3}$ Department of Oral and Maxillofacial Surgery, People's Dental \\ College and Hospital, Kathmandu, Nepal \\ ${ }^{4}$ Department of Prosthodontics, Chitwan Medical College, \\ Chitwan, Nepal \\ 5 International College of Dentistry, Walailuk University, \\ Nakhon Si Thammarat, Thailand
}

Manjeev Guragain ${ }^{1}$ Bashu Raj Pandey ${ }^{2} \quad$ Mahendra Maharjan ${ }^{3} \quad$ Samarika Dahal ${ }^{1}$

\begin{abstract}
Address for correspondence Manjeev Guragain, BDS, MDS, Department of Dentistry, Tribhuvan University Institute of Medicine, Kathmandu 44600, Nepal (e-mail: manjeevguragain@gmail.com).
\end{abstract}

Eur Dent Res Biomater J 2020;1:4-7

\begin{abstract}
Objective To assess the patient's level of awareness of dental implants as an option to replace missing teeth and willingness to accept dental implant is lacking in a small city (Chitwan) Nepal.

Materials and methods A cross-sectional survey was conducted on patients attending the prosthodontic, oral medicine and radiology clinics of Chitwan Medical College, Chitwan, Nepal. A self-administered questionnaire was used after pretesting through a pilot survey. The data analysis was done using SPSS version 20 (IBM Company, Chicago, USA).

Statistical Analysis Various parameters were compared using Two-Sample Independent T-Test. The level of significant was set at $p$ value $=0.05$.

Results A total of 84 subjects responded to the study. Only $47.6 \%$ of the participants have knowledge on dental implants. Majority of the participants ( $72 \%$ ) considered the costs to be affordable and equal number of the participants replied that they were ready for treatment with dental implant. Majority of the participants received information from their dentists (53.1\%) and from the friends and acquaintances (31.3\%). The patients in Chitwan have moderate awareness of dental implants. Majority of the

Keywords

- dental implant

- information

- awareness

- dental education participants are aware and willing to consider dental plant treatments.

Conclusions The patients in Chitwan have moderate awareness of dental implants. Majority of the participants are aware and willing to consider dental plant treatments. Proper information on dental implants should be provided to the patients so that they can accept the dental implant treatment.
\end{abstract}

\section{Introduction}

Dental aesthetic plays an important role in the facial appearance and smile. ${ }^{1,2}$ Missing teeth creates unpleasant aesthetics. The prosthetic treatment creates natural aesthetics following mechanical and biologic requirements. ${ }^{3}$

DOI https://doi.org/ 10.1055/s-0040-1710139.
Dental implants play an important role in the oral rehabilitation and have become a part of the routine dental treatment. ${ }^{4}$ Implants improve chewing efficiency, and aid in denture retention and stability. ${ }^{5,6}$ Successful implant treatment needs the best gingival aesthetic success along with stability and function of the implant. ${ }^{7}$ The information regarding 
dental implants for the patients is important for the dental treatment planning. ${ }^{8}$ Some studies conducted in different countries regarding the awareness on dental implants show varying results from low to high awareness. ${ }^{9-11}$

Studies regarding awareness of dental implants and the willingness to accept a dental implant are lacking in small cities in developing countries like Nepal. Hence, this study aimed to assess the patient's level of awareness of dental implants as an option to replace missing teeth and the willingness to accept dental implant in a small city (Chitwan) in Nepal.

\section{Materials and Methods}

A cross-sectional survey was conducted on patients older than 18 years attending the prosthodontic, oral medicine, and radiology clinics of Chitwan Medical College, Chitwan, Nepal. Ethical clearance was obtained from the Ethical Committee of Chitwan Medical College (number: CMC/ADM/2072/073-116). The subjects were selected based on convenient sampling. Informed consent was obtained from the participants. A self-administered questionnaire was used after pretesting through a pilot survey. The data analysis was done using SPSS version 20 (IBM Company; Chicago, Illinois, United States). Various parameters were compared using two-sample independent $t$-test. The level of significance was set at $P$ value $=0.05$.

\section{Results}

\section{Demographic Characteristics}

The demographic characteristics of the participants in this study are shown in the - Table $\mathbf{1}$. It showed that majority

Table 1 Demographic characteristics of the participants in this study

\begin{tabular}{|c|c|c|c|}
\hline $\begin{array}{l}\text { Demographic } \\
\text { characteristics }\end{array}$ & $\begin{array}{l}\text { Number } \\
\text { (n) }\end{array}$ & Percentage & $p$-Value \\
\hline \multicolumn{4}{|l|}{ Age } \\
\hline$<30 y$ & 47 & 56.0 & \multirow[t]{2}{*}{0.277} \\
\hline$\geq 30 y$ & 37 & 44.0 & \\
\hline \multicolumn{4}{|l|}{ Gender } \\
\hline Male & 46 & 54.8 & \multirow[t]{2}{*}{0.383} \\
\hline Female & 38 & 45.2 & \\
\hline \multicolumn{4}{|l|}{ Education } \\
\hline $\begin{array}{l}\text { College, high } \\
\text { school, or less }\end{array}$ & 67 & 79.7 & \multirow[t]{2}{*}{$<0.0001^{a}$} \\
\hline $\begin{array}{l}\text { University } \\
\text { degree }\end{array}$ & 17 & 20.2 & \\
\hline \multicolumn{4}{|l|}{ Occupation } \\
\hline Employed & 27 & 32.1 & \multirow[t]{2}{*}{$0.002^{\mathrm{a}}$} \\
\hline Unemployed & 57 & 67.9 & \\
\hline \multicolumn{4}{|l|}{ Location } \\
\hline Mountains & 74 & 88.1 & $<0.0001^{\mathrm{a}}$ \\
\hline Terai (plain land) & 10 & 11.9 & \\
\hline
\end{tabular}

asignificant at $p$-value $<0.05$. of the respondents were younger than 30 years (56\%) and males (54.8\%), and more than half of the respondents (47.6\%) completed education only till college, high school, or less. Only 17 respondents (20\%) held a university degree. Majority of the respondents $(88.1 \%)$ were from the mountain region, whereas only few $(12 \%)$ were from the study site (Terai, plain land). For the education, occupation, and location, there was significant difference between the groups $(p<0.05)$.

\section{Knowledge of the Participants on Dental Implant, its Affordability, and Treatment Consideration}

It was found that less than half of the respondents (47.6\%) only have knowledge on dental implants (-Table 2). It was also found that a greater number of the participants (71.9\%) think that the dental implants are affordable and want to consider the treatment. The participants who did not consider the dental implant treatment was due to unaffordability for the treatment, fear of surgical procedure, and lack of information ( - Fig. 1). For the affordability of treatment cost and treatment consideration with implants, there is significant difference between the groups $(p<0.05)$.

\section{Source of Information on Dental Implants}

Regarding the source of the information on dental implants, about half participants received information from their dentists (53.1\%) followed by friends and acquaintances (31.3\%),

Table 2 Knowledge of the participants on dental implants, their affordability, and treatment consideration

\begin{tabular}{|c|c|c|c|}
\hline Traits & Number $(n)$ & Percentage & $p$-Value \\
\hline \multicolumn{4}{|l|}{$\begin{array}{l}\text { Heard of dental } \\
\text { implant }\end{array}$} \\
\hline Yes & 40 & 47.6 & \multirow[t]{2}{*}{0.654} \\
\hline No & 44 & 52.4 & \\
\hline \multicolumn{4}{|c|}{ Affordability of treatment cost } \\
\hline Affordable & 23 & 71.9 & \multirow[t]{2}{*}{$0.025^{a}$} \\
\hline Not affordable & 9 & 28.1 & \\
\hline \multicolumn{4}{|c|}{ Consider treatment with implants } \\
\hline Yes & 23 & 71.9 & \multirow[t]{2}{*}{$0.025^{a}$} \\
\hline No & 9 & 28.1 & \\
\hline
\end{tabular}

aSignificant at $p$-value $<0.05$.

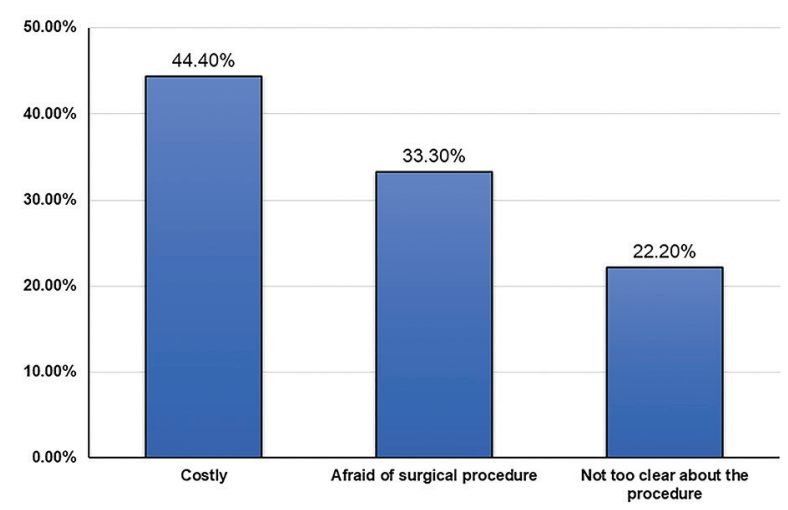

Fig. 1 Readiness on treatment with dental implants. 


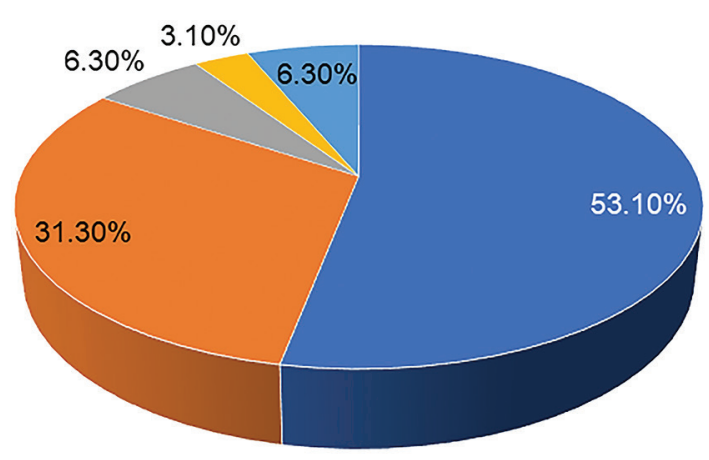

- Dentist

- Friends and acquaintances

- Someone who has already undergone this treatment

- Newspaper/magazines, TV/radio

$\square$ Others

Fig. 2 Source of information on dental implants.

other patients (2\%), newspapers/magazines/television/radio (1\%), and other sources (2\%), as shown in - Fig. 2 .

\section{Discussion}

Creating an aesthetic smile is a challenging procedure that requires a multidisciplinary approach and treatment planning. ${ }^{1}$ Various factors are essential in the dental and facial aesthetics, like soft tissues including facial proportions and hard tissues including teeth proportions..$^{12,13}$ Dental implants help in oral rehabilitation, functions, and dental aesthetics. ${ }^{14,15}$ Therefore, the patients should be aware of the dental implant treatment options for the replacement of teeth and aesthetic dental treatments. ${ }^{16}$

Most publications on dental implants emphasize on basic to clinical research. But the level of patient information on dental implants should not be neglected. Recently, the awareness and experience of dental implants in patients have been studied in various parts of the world. - $^{80,17-25}$ Similarly, this is the survey regarding the awareness of dental implants conducted in a tertiary-level hospital in Chitwan. The level of knowledge of the participants on dental implants in our study (47.6) is significantly lower than those found in the developed countries-by Zimmer et $\mathrm{a}^{18}$ in the United States (77\%), Berge ${ }^{26}$ in Norway (70.1\%), and by Tepper et $\mathrm{al}^{8}$ in Austria (72\%). However, the level of knowledge (47.6\%) on dental implants in our study which is done in a small city in Nepal is higher than that reported by Lajana et al ${ }^{19}$ in the capital city of Nepal (36.3\%), Kaurani and Kaurani in India (36.3\%), and Gbadebo et $\mathrm{l}^{9}$ in Nigeria (28.9\%). This might be correlated with the greater number participants with less education ( $\mathbf{- T a b l e s} \mathbf{1}, \mathbf{2}$ ). This might be due to lower educational level and socioeconomic status.

Dentists are the prime source of information of dental implants for the patients. Zimmer et $\mathrm{l}^{18}$ found that only $17 \%$ of the participants named a dentist or physician as the source of information but in our study more than half of the participants (53.1\%) received information on dental implants from the dentists. Most often, patients lack the information and rely on other sources of information. ${ }^{10}$ Hence, the dentists should provide information on dental implants as part of the treatment planning.

At present, the immediate implant placement is done to limit bone resorption following tooth extraction and also to reduce the number of surgical procedures. ${ }^{27}$ Hence, the patients are also made aware of the various implant placement techniques, such as immediate implant placement, one-stage stage implant placement, and two-stage implant placement. ${ }^{27,28}$

Furthermore, in implant dentistry, researchers are also developing newer surface-treated and coated implants to improve the osseointegration by interactions between proteins, cells and tissues, and bone grafts to deal with bone defects and peri-implantitis. ${ }^{29-31}$ This information should also be given to the patients. The results of this study might act as a baseline data to formulate the patient's education and motivation strategies to pave way for its ready acceptability in the society.

\section{Conclusions}

The patients in Chitwan have moderate awareness of dental implants. Majority of the participants are aware and willing to consider dental implant treatments. Dentists are the chief source of information regarding the dental implants for the patients. Proper information to the patients regarding implants is important so that they can accept the dental implant treatment.

\section{Authors' Contributions}

All authors contributed to this research and the manuscript.

\section{Ethical Approval}

This study was approved by the Ethical Committee of Chitwan Medical College, Chitwan, Nepal. Number: CMC/ ADM/2072/073-116.

\section{Conflict of Interest}

None declared.

\section{References}

1 Donitza A. Creating the perfect smile: prosthetic considerations and procedures for optimal dentofacial esthetics. J Calif Dent Assoc 2008;36(5):335-340

2 Rokaya D, Kitisubkanchana J, Wonglamsam A, Santiwong P, Srithavaj T, Humagain M. Nepalese esthetic dental (NED) proportion in Nepalese population. Kathmandu Univ Med J (KUMJ) 2015;13(51):244-249

3 McLaren EA, Rifkin R. Macroesthetics: facial and dentofacial analysis. J Calif Dent Assoc 2002;30(11):839-846

4 Gaviria L, Salcido JP, Guda T, Ong JL. Current trends in dental implants. J Korean Assoc Oral Maxillofac Surg 2014;40(2):50-60

5 Doornewaard R, Glibert M, Matthys C, Vervaeke S, Bronkhorst E, de Bruyn H. Improvement of quality of life with implant-supported mandibular overdentures and the effect of implant type and surgical procedure on bone and soft tissue stability: a three-year prospective split-mouth trial. J Clin Med 2019;8(6):773 
6 Amornvit P, Rokaya D, Bajracharya S, Keawcharoen K, Supavanich W. Management of obstructive sleep apnea with implant retained mandibular advancement device. World J Dent 2014;5(3):184-189

7 Somanathan RV, Simůnek A, Bukac J, Brázda T, Kopecká D. Soft tissue esthetics in implant dentistry. Acta Med (Hradec Kralove) 2007;50(3):183-186

8 Tepper G, Haas R, Mailath G, et al. Representative marketingoriented study on implants in the Austrian population. I. Level of information, sources of information and need for patient information. Clin Oral Implants Res 2003;14(5):621-633

9 Gbadebo OS, Lawal FB, Sulaiman AO, Ajayi DM. Dental implant as an option for tooth replacement: the awareness of patients at a tertiary hospital in a developing country. Contemp Clin Dent 2014;5(3):302-306

10 Kashbour WA, Rousseau NS, Thomason JM, Ellis JS. Provision of information on dental implant treatment: patients' thoughts and experiences. Clin Oral Implants Res 2018;29(3):309-319

11 Suwal P, Basnet B, Shrestha B, Parajuli P, Singh R. Knowledge, attitude, and awareness regarding dental implants among patients visiting a university hospital and its teaching districts. J Dent Implant 2016;6(2):57-61

12 Rokaya D, Humagain M, Amornvit P. Maxillary anterior teeth proportions for creating esthetically pleasuring smile in Nepalese Patients. J Nepal Health Res Counc 2018;16(3):362

13 Rokaya D, Suttagul K, Sapkota B, Maharjan SK. Gender based comparison of the relationships of maxillary anterior teeth and facial measurements. J Int Dent Med Res 2018;11(1):465-469

14 Lindh T, Gunne J, Tillberg A, Molin M. A meta-analysis of implants in partial edentulism. Clin Oral Implants Res 1998;9(2):80-90

15 Adell R, Eriksson B, Lekholm U, Brånemark PI, Jemt T. Longterm follow-up study of osseointegrated implants in the treatment of totally edentulous jaws. Int J Oral Maxillofac Implants 1990;5(4):347-359

16 Ishida Y, Fujimoto K, Higaki N, Goto T, Ichikawa T. End points and assessments in esthetic dental treatment. J Prosthodont Res 2015;59(4):229-235

17 Best HA. Awareness and needs of dental implants by patients in New South Wales. Aust Prosthodont J 1993;7:9-12

18 Zimmer CM, Zimmer WM, Williams J, Liesener J. Public awareness and acceptance of dental implants. Int J Oral Maxillofac Implants 1992;7(2):228-232

19 Shrestha L, Shrestha B, Dixit S. Patients' awareness of dental implants as an option for tooth replacement: a survey in Kathmandu valley, Nepal. Int J Sci Res (Ahmedabad) 2017;6(9):61-63
20 Chowdhary R, Mankani N, Chandraker NK. Awareness of dental implants as a treatment choice in urban Indian populations. Int J Oral Maxillofac Implants 2010;25(2):305-308

21 Kohli S, Bhatia S, Kaur A, Rathakrishnan T. Patients awareness and attitude towards dental implants. Indian J Dent 2015;6(4):167-171

22 Siddique EA, Bhat PR, Kulkarni SS, Trasad VA, Thakur SL. Public awareness, knowledge, attitude and acceptance of dental implants as a treatment modality among patients visiting SDM College of Dental Sciences and Hospital, Dharwad. J Indian Soc Periodontol 2019;23(1):58-63

23 Hosadurga R, Shanti T, Hegde S, Kashyap RS, Arunkumar SM. Awareness, knowledge, and attitude of patients toward dental implants-a questionnaire-based prospective study. J Indian Soc Periodontol 2017;21(4):315-325

24 Mayya A, D’Souza J, George AM, Shenoy K, Jodalli P, Mayya SS. Knowledge and awareness of dental implants as a treatment choice in adult population in South India: a hospital-based study. Indian J Dent Res 2018;29(3):263-267

25 Suprakash B, Ahammed ARY, Thareja A. Kandaswamy R, Nilesh $\mathrm{K}$, Bhondwe Mahajan S. Knowledge and attitude of patients toward dental implants as an option for replacement of missing teeth. J Contemp Dent Pract 2013;14(1):115-118

26 Berge TI. Public awareness, information sources and evaluation of oral implant treatment in Norway. Clin Oral Implants Res 2000;11(5):401-408

27 Javaid MA, Khurshid Z, Zafar MS, Najeeb S. Immediate implants: clinical guidelines for esthetic outcomes. Dent J (Basel) 2016;4(2):21

28 Amornvit P, Rokaya D, Keawcharoen K, Raucharernporn S, Thongpulsawasdi N. One- vs two-stage surgery technique for implant placement in finger prosthesis. J Clin Diagn Res 2013;7(9):1956-1968

29 Le Guéhennec L, Soueidan A, Layrolle P, Amouriq Y. Surface treatments of titanium dental implants for rapid osseointegration. Dent Mater 2007;23(7):844-854

30 Rokaya D, Srimaneepong V, Sapkota J, Qin J, Siraleartmukul K, Siriwongrungson V. Polymeric materials and films in dentistry: an overview. J Adv Res 2018;14:25-34

31 Najeeb S, Mali M, Yaqin SAU, et al. Dental implants materials and surface treatments. In: Khurshid Z, Najeeb S, Zafar MS, Sefat F, eds. Advanced Dental Biomaterials. 1st ed. Cambridge, UK: Woodhead Publishing; 2019 581-598 